Volume 10 Nomor 2, April 2019, p.019-033.

Faculty of Law, Universitas Kristen Maranatha

ISSN: 2085-9945 I e-ISSN: 2579-3520

Nationally Accredited Journal by SINTA

\title{
Tinjauan Yuridis Tindakan Delisting Oleh Bursa Efek Indonesia dan Perlindungan Pemegang Saham (Studi Kasus: PT. Berau Coal Energy, Tbk.)
}

\author{
Louise Ruselis Sitorus
}

Faculty of Law, University of Indonesia

louiseruselissitorus@yahoo.com

Submitted: 2018-12-15; Reviewed: 2019-04-10; Accepted: 2019-04-30

\begin{abstract}
A public-listed company essentially is required to be aware of all of its consequences and obligations inter alia protecting the interests of minority shareholders, conducting information disclosure and acting in accordance with relevant national laws and regulations. If such obligations are neglected, the company may jeopardize its existence in the stock exchange listing. It may be delisted. A delisted company has obligations to convey delisting decision to their investors as information disclosure and acting in accordance with relevant national laws and regulations. However, a delisted company does not automatically turn its status from public-listed company to Private Company. As long as the company runs with fulfilled requirements to become a public-listed company, it still bears the aforementioned obligations.

There is a wrong assumption that a delisted company will be harm the shareholders. delisting company prevents an even greater loss of investors from letting investors invest in unprofitable companies. Whereas investors invest their shares with the aim to gain profits. Investors can also make various efforts to get protection.
\end{abstract}

Keywords: Capital Market; delisting; public-listed company

\section{PENDAHULUAN}

Pasar modal mempunyai peran strategis sebagai salah satu sumber pembiayaan bagi dunia usaha, termasuk usaha menengah dan kecil untuk pembangunan usahanya, sedangkan di sisi lain pasar modal juga merupakan wahana investasi bagi masyarakat, termasuk pemodal kecil dan menengah. 
Pasar modal menurut Undang-Undang No. 8 Tahun 1995 adalah kegiatan yang bersangkutan dengan penawaran umum dan perdagangan efek, perusahaan publik yang berkaitan dengan efek yang diterbitkannya, serta lembaga dan profesi yang berkaitan dengan efek. ${ }^{1}$ Investor dapat melakukan investasi pada beberapa perusahaan melalui pembelian efek-efek yang baru ditawarkan ataupun yang diperdagangkan di pasar modal. Sebaliknya, perusahaan dapat memperoleh dana yang dibutuhkan dengan menawarkan instrumen keuangan jangka panjang melalui pasar modal tersebut.

Penawaran Umum adalah kegiatan penawaran saham atau efek yang dilakukan oleh emiten kepada masyarakat berdasarkan tata cara yang diatur oleh Undang-Undang dan peraturan pelaksanaannya. ${ }^{2}$ Penawaran umum dapat dijadikan sarana untuk alternatif dana bagi sebuah perusahaan. Apabila sebuah perusahaan sudah melakukan penawaran umum (go public), maka konsekuensinya adalah perusahaan tersebut harus bersikap terbuka (disclosure) kepada masyarakat terutama kepada para pemegang saham atau investor dari perusahaan tersebut. ${ }^{3}$

Bila penawaran umum perdana telah berhasil dengan baik, maka bukan berarti pekerjaan telah selesai. Selesainya penawaran umum perdana berarti awal dari kehidupan baru perusahaan dan juga berarti permulaan dari masa depan perusahaan yang sangat berbeda. ${ }^{4}$ Untuk itu, setelah perusahaan tersebut go public, perusahaan tersebut dapat melakukan pencatatan (listing) atas saham yang dikeluarkannya di Bursa Efek. Apabila sudah tercatat, maka efek secara resmi bisa diperjualbelikan di Bursa bersangkutan. ${ }^{5}$ Tujuan pencatatan ini sendiri adalah agar saham-sahamnya akan mudah ditransaksikan oleh para pemodal, yang telah membelinya atau pemodal yang ingin membeli sahamsaham tersebut. ${ }^{6}$

Istilah pencatatan (Listing) sendiri dirumuskan sebagai pencantuman suatu efek dalam daftar efek yang tercatat di bursa sehingga dapat diperdagangkan di bursa. ${ }^{7}$ Perusahaan tersebut wajib menyampaikan informasi penting yang berkaitan dengan tindakan atau Efek tersebut pada waktu yang tepat kepada masyarakat dalam bentuk laporan berkala dan laporan peristiwa penting. ${ }^{8}$

Emiten dituntut untuk mengungkapkan informasi mengenai keadaan bisnisnya, termasuk keadaan keuangan, aspek hukum dari harta kekayaan, persoalan hukum yang dihadapi perusahaan dan manajemen. ${ }^{9}$ Banyak faktor mengapa saham kurang diminati oleh pemodal, antara lain buruknya kinerja fundamental emiten sehingga secara signifikan mempengaruhi kelangsungan usaha. Misalnya emiten mengalami

\footnotetext{
${ }^{1}$ Indonesia, Undang-Undang Tentang Pasar Modal, UU No. 8 Tahun 1995, LN No. 64 Tahun 1995, TLN No. 3608, Pasal 1 angka 13.

${ }^{2}$ Ibid., Pasal 1 angka 15

${ }^{3}$ M. Irsan Nasarudin, et. al., Aspek Hukum Pasar Modal Indonesia, Jakarta: Prenada Media Group, 2007, hlm. 165.

${ }^{4}$ Ibid., hlm. 213.

${ }^{5}$ E. A. Koetin, Analisis Pasar Modal, Jakarta: Pustaka Sinar Harapan, 2002, hlm. 100.

${ }^{6}$ Hamud M. Balfas, Hukum Pasar Modal Indonesia, Jakarta: PT. Tata Nusa, 2006, hlm. 290.

${ }^{7}$ Bursa Efek Indonesia, Peraturan Pencatatan Efek No. I-A Tentang Pencatatan Saham dan Efek Bersifat Ekuitas Selain Saham yang Diterbitkan oleh Perusahaan Tercatat, Keputusan Direksi PT. Bursa Efek Jakarta No. Kep-305/BEJ/07-2004, Pasal I.16.

${ }^{8}$ Indonesia, Undang-Undang Tentang Pasar Modal, Pasal 86 ayat 1.

${ }^{9}$ M. Irsan Nasarudin, et. al., op. cit., hlm. 229.
} 
kerugian beberapa tahun terakhir secara berturut-turut, hal tersebut tentu akan berdampak pada return yang akan diterima oleh pemodal, dalam hal ini adalah dividen yang diterima oleh pemodal akan turun bahkan nol. ${ }^{10}$ Pada gilirannya daya tarik emiten tersebut tidak ada sehingga para pemodal enggan menginvestasikan dana mereka pada saham tersebut, atau faktor keterbukaan informasi (information disclosure), faktor keterbukaan ini penting, sebab meskipun fundamental perusahaan baik, tetapi emiten kurang terbuka, sehingga peminatnya tidak ada. Faktor lainnya yaitu apabila emiten melanggar peraturan-peraturan di bidang pasar modal. Apabila hal tersebut terjadi pada perusahaan go public, emiten tersebut bisa dihapuskan dari pencatatan di bursa atau disebut delisting. ${ }^{11}$

Saham yang telah tercatat di bursa (listed) dapat mengalami apa yang disebut sebagai delisting, yaitu penghapusan pencatatan dari daftar saham di bursa. ${ }^{12}$ Bursa efek mengatur ketentuan mengenai delisting dan relisting melalui Peraturan Nomor I-I tentang Penghapusan Pencatatan (delisting) dan Pencatatan Kembali (relisting) saham di bursa, yang efektif berlaku sejak tanggal 19 Juli 2004. Menurut Angka I.I4 Peraturan I-I tentang Penghapusan Pencatatan (delisting) dan Pencatatan Kembali (relisting) saham di bursa, Penghapusan Pencatatan (delisting) adalah penghapusan efek yang tercatat di Bursa sehingga Efek tersebut tidak dapat diperdagangkan di Bursa. ${ }^{13}$

Penghapusan pencatatan saham perusahaan tercatat dari daftar efek yang tercatat di bursa dapat terjadi karena: ${ }^{14}$

a. Permohonan penghapusan pencatatan saham yang diajukan oleh perusahaan tercatat sendiri, yang biasanya disebut voluntary delisting;

b. Dihapus pencatatannya oleh bursa sesuai dengan ketentuan bursa karena tidak lagi memenuhi persyaratan yang ditentukan oleh bursa, yang biasanya disebut forced delisting.

Delisting merupakan peristiwa penting dan mempunyai pengaruh yang sangat besar bagi pemegang saham. Ini karena delisting juga merupakan salah satu tanda adanya ketidakberesan dalam pengelolaan emiten yang bersangkutan. Seperti telah dijelaskan di atas, delisting dibedakan menjadi dua yakni voluntary delisting dan forced delisting. Delisting jenis terakhir inilah yang merupakan salah satu tanda adanya ketidakberesan dalam pengelolaan perusahaan. Pengaruh paling besar dari

\footnotetext{
${ }^{10}$ Isabelle Martinez, et. al., "Reasons for Delisting and Consequences: A Literature Review and Research Agenda", Journal of Economic Surveys, Volume 31, Issue 3, (July 2016), hlm. 7.

${ }^{11}$ Sunariyah, Pengantar Pengetahuan Pasar Modal, Yogyakarta: Sekolah Tinggi Ilmu Manajemen (YKPN), 2011, hlm. 38.

${ }^{12}$ Saleh Basir dan Hendy M. Fakhrudin, Aksi Korporasi, Jakarta: PT. Salemba Empat, 2005, hlm. 49.

13 Bursa Efek Indonesia, Peraturan No. I-I Tentang Penghapusan Pencatatan (delisting) dan Pencatatan Kembali (relisting) saham di bursa, Keputusan Direksi PT Bursa Efek Jakarta No. Kep308/BEJ/07-2004, Pasal I.14.

${ }^{14}$ Ibid., Pasal III.1.
} 
delisting adalah hilangnya likuiditas atas efek/saham tersebut, dan ini dapat mempengaruhi harga dari efek tersebut. ${ }^{15}$

Delisting yang disebabkan oleh kemauan pemegang saham dan perusahaan, haruslah mendapat persetujuan dari pemegang saham. Sedangkan delisting yang dilakukan oleh bursa adalah karena emiten tidak lagi dapat memenuhi persyaratan yang ditetapkan oleh bursa. Penulis akan memfokuskan pada pembahasan mengenai penghapusan pencatatan saham oleh bursa, yang dinamakan dengan forced delisting.

Dengan didelistingnya suatu efek perusahaan di bursa, bukan berarti perusahaan tersebut berubah menjadi perusahaan tertutup. Selama perusahaan tersebut masih memiliki status sebagai perusahaan publik, maka perusahaan tersebut tetap memiliki kewajiban-kewajiban yang harus dipenuhi sebagai perusahaan publik, antara lain ialah tetap memenuhi ketentuan mengenai keterbukaan informasi dan pelaporan kepada Bapepam-LK serta tetap wajib memperhatikan kepentingan pemegang saham publik atau bisa dikatakan sebagai pemegang saham minoritas.

Delisting atas suatu saham dari daftar Efek yang dilakukan oleh bursa terjadi jika Perusahaan Tercatat mengalami sekurangnya satu kondisi di bawah ini: ${ }^{16}$

a. Mengalami kondisi, atau peristiwa, yang secara signifikan berpengaruh negatif terhadap kelangsungan usaha perusahaan tercatat, baik secara finansial atau secara hukum atau terhadap kelangsungan status perusahaan tercatat sebagai perusahaan terbuka, dan perusahaan tercatat tidak dapat menunjukkan indikasi pemulihan yang memadai.

b. Saham perusahaan tercatat yang akibat suspensi di pasar regular dan tunai, hanya diperdagangkan di pasar negosiasi sekurang-kurangnya selama 24 (dua puluh empat) bulan terakhir.

Apabila Emiten pernah di-force delisting oleh bursa, maka biasanya memiliki image yang lebih negatif dibandingkan dengan voluntary delisting. Hal ini disebabkan karena biasanya emiten yang di-forced delisting itu memiliki kinerja perusahaan yang buruk sehingga mempengaruhi harga saham dan bursa tidak likuid. ${ }^{17}$ Delisting itu merupakan pilihan terakhir bursa, sehingga sebelum dilakukan delisting, bursa memberikan early warning terlebih dahulu agar emiten dapat memperbaiki kondisi perusahaannya ataupun memenuhi ketentuan yang dilanggarnya. Oleh karena itu, tujuan delisting bukan untuk mematikan perusahaan, tetapi untuk memberikan kesempatan bagi perusahaan tersebut untuk

\footnotetext{
${ }^{15}$ Hamud Balfas, Hukum Pasar Modal Indonesia, Jakarta: PT Tata Nusa, 2006, hlm. 306.

16 Bursa Efek Indonesia, Peraturan No. I-I Tentang Penghapusan Pencatatan (delisting) dan Pencatatan Kembali (relisting) saham di bursa, Keputusan Direksi PT Bursa Efek Jakarta No. Kep308/BEJ/07-2004, Pasal III.3.1.

${ }^{17}$ Haykel Widiasmoko, “Analisa Delisting: Penerapan Delisting di PT. Bursa Efek Jakarta dan Akibat Hukum Suatu Perseroan yang Terkena Sanksi Delisting”, Skripsi Universitas Indonesia, 1999, hlm. 50.
} 
mengadakan perbaikan, agar bisa diadakan relisting, atau masuk kembali ke daftar kurs resmi, demi kebahagiaan para pemegang saham. ${ }^{18}$

Tetapi jika delisting adalah jalan terbaik bagi perusahaan dan tidak dapat terhindarkan lagi, dibutuhkan prosedur delisting saham oleh bursa, yaitu apabila terdapat indikasi bahwa Perusahaan Tercatat mengalami satu atau lebih kondisi sebagaimana dimaksud dalam Ketentuan III.3.1 Peraturan No. I-I Tentang Penghapusan Pencatatan (delisting) dan Pencatatan Kembali (relisting) saham di bursa, yakni mengalami kondisi, atau peristiwa yang secara signifikan berpengaruh negatif terhadap kelangsungan usaha Perusahaan Tercatat sebagai Perusahaan Terbuka, dan Perusahaan Tercatat tidak dapat menunjukkan indikasi pemulihan yang memadai, dan/atau telah mengalami penghentian sementara perdagangan saham di bursa (suspensi) sekurang-kurangnya 24 (dua puluh empat) bulan terakhir, maka Bursa melakukan Dengar Pendapat dengan Perusahaan Tercatat. ${ }^{19}$

Salah satu contoh perusahaan yang telah mengalami proses delisting oleh bursa, khususnya forced delisting adalah PT. Berau Coal Energy, Tbk atau yang biasa dikenal dengan kode saham BRAU. BRAU ini didirikan dengan nama PT. Risco pada September 2005. Berdasarkan Anggaran Dasar Perusahaan, ruang lingkup kegiatan BRAU bergerak di bidang usaha pertambangan batubara. Pada Agustus 2010, BRAU telah memperoleh pernyataan efektif dari Bapepam-LK untuk melakukan Penawaran Umum Perdana Saham BRAU atau dikenal dengan IPO (Initial Public Offering). Di sinilah BRAU dicatatkan sahamnya di Bursa Efek Indonesia dan mendapatkan kode saham BRAU. Namun demikian sejak 2013 BRAU tidak lagi mempunyai pendapatan atau kelangsungan usahanya telah terganggu, yang di mana padahal pada April 2012, saham BRAU sempat menyentuh level tertinggi sepanjang sejarah. Puncaknya, Juli 2015 BRAU diketahui gagal melakukan pembayaran utang sebesar US\$ 450 juta yang jatuh tempo pada saat itu. ${ }^{20}$ Oleh sebab itu Bursa Efek Indonesia menjatuhkan hukuman suspensi atau pemberhentian sementara perdagangan saham pada perusahaan tersebut di bursa pada Oktober 2015. Setelah melewati masa suspensi, perusahaan tersebut tidak menunjukan perbaikan yang diharapkan, tetapi mengalami kondisi yang secara signifikan berpengaruh negatif terhadap keberlangsungan usaha perusahaan. Oleh karena itulah pada tanggal 16 November 2017 Bursa telah melakukan delisting terhadap BRAU (forced delisting).

Penulis ingin membahas lebih lanjut mengenai proses forced delisting yang dilakukan oleh Bursa Efek Indonesia kepada PT. BERAU COAL ENERGY, Tbk. (BRAU), hingga pembahasan tersebut tertuju kepada perlindungan bagi pemegang

\footnotetext{
${ }^{18}$ E. A. Koetin, op. cit., hlm. 95.

${ }^{19}$ Keputusan Direksi PT. Bursa Efek Jakarta Nomor : Kep-308/BEJ/07-2004 Tentang Peraturan Nomor I-I Tentang Penghapusan Pencatatan (Delisting) Dan Pencatatan Kembali (Relisting) Saham di Bursa Pasal III.3

${ }^{20}$ Danang Sugianto, "Saham Berau Dulu Primadona, Sekarang 'Ditendang' dari Bursa", Detik Finance, diakses dari https://finance.detik.com/bursa-valas/3695726/saham-berau-duluprimadona-sekarang-ditendang-dari-bursa, diakses pada tanggal 16 November 2018 pukul 16.07 WIB
} 
saham untuk perseroan yang mengalami delisting. Karya tulis ini Berjudul TINJAUAN YURIDIS TINDAKAN DELISTING OLEH BURSA EFEK INDONESIA DAN PERLINDUNGAN PEMEGANG SAHAM (STUDI KASUS: PT. BERAU COAL ENERGY, Tbk.)

\section{PEMBAHASAN}

PT Berau Coal Energy Tbk. (BRAU) resmi terhapus dari daftar perusahaan terbuka di Bursa Efek Indonesia (BEI). Emiten ini resmi delisting lewat informasi yang diumumkan BEI dengan surat No: Peng-DEL-00002/BEI.PP1/11-2017 tentang Pengumuman Penghapusan Pencatatan Efek PT. Berau Coal Energy Tbk. (BRAU). BRAU memulai perjalanannya dari pencatatan saham perdana (listing) BRAU pada Agustus 2010. Pada tanggal 6 Agustus 2010, BRAU memperoleh pernyataan efektif dari Bapepam-LK untuk melakukan Penawaran Umum Perdana Saham BRAU (IPO) kepada masyarakat sebanyak 3.400.000.000 (3,4 milyar) dengan nilai nominal Rp 100,- per lembar saham, saham dengan harga penawaran Rp 400,- per lembar saham. Saham-saham tersebut dicatatkan pada Bursa Efek Indonesia (BEI) pada tanggal 19 Agustus 2010. Berperan sebagai penjamin pelaksana efek (underwriter) pada saat pelaksanaan IPO adalah PT. Danatama Makmur dan PT. Recapital Securities. $^{21}$

Saham BRAU pun cukup diminati pelaku pasar kala itu. Terbukti dari pergerakan sahamnya yang terus menguat. Pada April 2012, saham BRAU sempat menyentuh level tertinggi sepanjang sejarah yakni di level Rp 540 per saham. Pada Juli 2015 BRAU diketahui gagal melakukan pembayaran utang sebesar US\$ 450 juta (Rp 5,85 triliun) yang jatuh tempo pada saat itu. ${ }^{22}$ Surat utang itu diterbitkan oleh anak usaha perseroan di Singapura, Berau Capital Resources Pte. Ltd (BCR). Anak usahanya itu tak bisa membayar utang setelah melewati batas waktu pembayaran. $^{23}$

Proses restrukturisasi utang BRAU masih sulit dilakukan dan menemui hambatan, pada saat yang sama, BRAU belum memberikan laporan keuangan terakhir, namun dalam laporan keuangan tahunan perseroan pada 2014 disebutkan, jumlah aset yang dimiliki sebanyak US\$ 1.773 juta, dan total liabilitas lancar sebanyak US\$1.288 juta, ditambah liabilitas jangka panjang US\$ 527 juta, dengan total utang sebesar US\$1.815 juta.

\footnotetext{
${ }^{21}$ Rheza Andhika Pamungkas, "Listing Perdana, Saham Berau Langsung Melesat", Okezone Finance, diakses dari https://economy.okezone.com/read/2010/08/19/278/364378/listing-perdanasaham-berau-langsung-melesat, diakses pada tanggal 16 November 2018 pukul 16.11 WIB

${ }^{22}$ Danang Sugianto, "Saham Berau Dulu Primadona, Sekarang 'Ditendang' dari Bursa", Detik Finance, diakses dari https://finance.detik.com/bursa-valas/3695726/saham-berau-duluprimadona-sekarang-ditendang-dari-bursa, diakses pada tanggal 16 November 2018 pukul 16.07 WIB

${ }^{23}$ Angga Aliya, "Berau Coal Tak Mampu Bayar Utang Rp 5,8 Triliun", Detik Finance, diakses dari https://finance.detik.com/bursa-valas/2965830/berau-coal-tak-mampu-bayar-utang-rp-58-triliun, diakses pada tanggal 17 November 2018 pukul 17.11 WIB
} 
BRAU mendapat tingkat kerugian bersih selama tahun berjalan 2014 sebesar US\$ 85 juta dan modal kerja bersih US\$ 421 juta. Dengan kondisi keuangan tersebut, restrukturisasi utang cukup sulit dilakukan karena besar utang tidak sebanding dengan aset yang dimiliki.

Sejak 4 Mei 2015, Bursa Efek Indonesia telah melakukan penghentian perdagangan efek perseroan di seluruh pasar, BRAU mengalami suspensi perdagangan di semua pasar saham, selama hampir dua tahun. Suspensi perdagangan saham tersebut antara lain disebabkan oleh ketidakjelasan pelaksanaan RUPSLB yang dilaksanakan pada 30 April 2015. Suspensi perseroan dilakukan di pasar reguler dan tunai sejak 30 Juni 2015.

Nasib perseroan pun tak jelas lantaran tak menyampaikan laporan keuangan pada semester I-2015 dan belum membayar denda. BEI pun menjatuhkan hukuman suspensi atas saham BRAU pada 30 Oktober 2015. Bertepatan dengan hal tersebut, saat itu saham BRAU sudah terkapar di level Rp 82 per lembar.

Hingga akhirnya Bursa Efek Indonesia memutuskan untuk memperpanjang penghentian sementara saham BRAU. Perpanjangan tersebut efektif dilakukan pada perdagangan Sesi I, 21 Desember 2015. Selanjutnya, perseroan dalam keterbukaan informasi 18 Oktober 2017 mengungkapkan bahwa sehubungan dengan penghapusan pencatatan (delisting) oleh Bursa maka otoritas membuka suspensi perdagangan saham dan kepada pemegang efek diberikan kesempatan untuk memperdagangkan efek hanya di pasar negosiasi selama 20 hari bursa atau mulai 19 Oktober 2017 hingga 15 November 2017. ${ }^{24}$

Kini, tak terhindarkan lagi, saham BRAU, yang saat harga batu bara tengah booming, saham ini pernah menjadi primadona di antara emiten sejenis lainnya, akhirnya tetap berujung dihapus (delisting) oleh PT Bursa Efek Indonesia (BEI), terhitung sejak 16 November 2017.

\section{Penyebab Delisting Bursa Efek Indonesia Kepada PT. Berau Coal Energy (BRAU)}

Seperti sudah disinggung di atas bahwa delisting dibedakan menjadi dua yakni voluntary delisting dan forced delisting. Forced delisting merupakan salah satu tanda adanya ketidakberesan dalam pengelolaan perusahaan. Pengaruh paling besar dari delisting adalah hilangnya likuiditas atas efek/saham tersebut, dan ini dapat mempengaruhi harga dari efek tersebut. ${ }^{25}$

Sudah sangat jelas tercantum dalam Peraturan No. I-I Tentang Penghapusan Pencatatan (delisting) dan Pencatatan Kembali (relisting) saham di bursa, Keputusan Direksi PT Bursa Efek Jakarta No. Kep-308/BEJ/07-2004, Pasal III.3.1., Delisting atas suatu saham dari daftar Efek yang dilakukan oleh bursa

\footnotetext{
${ }^{24}$ Lukas Hendra TM, "Berau Coal Energy (BRAU) Resmi Jadi Perusahaan Tertutup”, Bisnis.com, diakses dari http://market.bisnis.com/read/20171115/192/709416/berau-coal-energy-brau-resmijadi-perusahaan-tertutup, diakses pada tanggal 17 November 2018 pukul 16.11 WIB

${ }^{25}$ Hamud M. Balfas, op. cit., hlm. 306.
} 
terjadi jika Perusahaan Tercatat mengalami sekurangnya satu kondisi di bawah ini: ${ }^{26}$

a. Mengalami kondisi, atau peristiwa, yang secara signifikan berpengaruh negatif terhadap kelangsungan usaha perusahaan tercatat, baik secara finansial atau secara hukum atau terhadap kelangsungan status perusahaan tercatat sebagai perusahaan terbuka, dan perusahaan tercatat tidak dapat menunjukkan indikasi pemulihan yang memadai.

b. Saham perusahaan tercatat yang akibat suspensi di pasar regular dan tunai, hanya diperdagangkan di pasar negosiasi sekurang-kurangnya selama 24 (dua puluh empat) bulan terakhir.

Berikut ini beberapa hal yang merupakan pelanggaran yang dilakukan oleh BRAU:

a. BRAU diketahui gagal melakukan pembayaran utang sebesar US\$ 450 juta (Rp 5,85 triliun) yang jatuh tempo pada saat itu

b. Saham BRAU disuspensi karena belum menyampaikan laporan keuangan interim pada semester I-2015

c. BRAU belum melakukan pembayaran denda atas keterlambatan penyampaian laporan keuangan tersebut.

d. Kekisruhan manajemen, akibat ketidakjelasan pelaksanaan RUPSLB

e. Saham BRAU sudah terkena suspensi dan hanya diperdagangkan di pasar negosiasi sekurang-kurangnya selama 24 bulan terakhir.

Dari kelima hal tersebut di atas, terbuktilah bahwa sesuai dengan Peraturan No. I-I Tentang Penghapusan Pencatatan (delisting) dan Pencatatan Kembali (relisting) saham di bursa, Keputusan Direksi PT Bursa Efek Jakarta No. Kep308/BEJ/07-2004, Pasal III.3.1., BRAU mengalami hal sebagai berikut:

1. Mengalami kondisi, atau peristiwa, yang secara signifikan berpengaruh negatif terhadap kelangsungan usaha perusahaan tercatat, baik secara finansial atau secara hukum, atau terhadap kelangsungan status perusahaan tercatat sebagai perusahaan terbuka, dan perusahaan tercatat tidak dapat menunjukkan indikasi pemulihan yang memadai.

Sejak Mei 2015, BRAU telah mengalami suspensi atau penghentian sementara perdagangan saham yang diakibatkan karena adanya ketidakpastian terhadap kelangsungan usaha perseroan. Suspensi ini terjadi terutama dikarenakan kondisi keuangan perusahaan yang kurang baik dan terus terjadi tanpa adanya usaha perbaikan yang signifikan sehingga mencapai limit waktu maksimal suspensi yang diberikan oleh Bursa yaitu selama 24 bulan ( 2 tahun).

\footnotetext{
26 Bursa Efek Indonesia, Peraturan No. I-I Tentang Penghapusan Pencatatan (delisting) dan Pencatatan Kembali (relisting) saham di bursa, Keputusan Direksi PT Bursa Efek Jakarta No. Kep308/BEJ/07-2004, Pasal III.3.1.
} 
Pada saat Bursa memberlakukan suspensi terhadap BRAU, perusahaan masih memiliki kewajiban pinjaman yang masih belum diselesaikan hingga jatuh tempo sebesar US\$ 450 juta (Rp 5,85 triliun) dan kondisi tersebut berdampak buruk terhadap kinerja Perusahaan dan Anak Perusahaan (Berau Capital Resources Pte. Ltd (BCR)). Selain itu, saham PT Berau Coal Energy Tbk (BRAU) disuspensi karena belum menyampaikan laporan keuangan interim pada semester I-2015. BRAU belum melakukan pembayaran denda atas keterlambatan penyampaian laporan keuangan tersebut. Seperti telah dijelaskan di atas bahwa perusahaan tercatat wajib menyampaikan informasi penting yang berkaitan dengan tindakan atau Efek tersebut pada waktu yang tepat kepada masyarakat dalam bentuk laporan berkala dan laporan peristiwa penting. ${ }^{27}$ Oleh karena itu penyampaian laporan keuangan perseroan yang terlambat akan dikenakan denda dan pasti pemegang saham akan menderita kerugian.

Belum berakhir sampai di situ, masalah hukum yang terjadi dalam manajemen BRAU di mana Serikat Pekerja BRAU menuntut pembatalan hasil Rapat Umum Pemegang Saham Luar Biasa (RUPSLB) 30 April 2015 juga turut menjadi alasan penguat untuk bursa melakukan delisting pada BRAU. Posisi Keith dan Paul di jajaran direksi BRAU dipandang tidak sah lantaran dituduh terjerat pelanggaran imigrasi dan dinyatakan tidak memiliki izin bekerja di BRAU. Pejabat imigrasi sudah menyatakan bahwa keduanya dilarang bekerja dan melakukan tindakan yang mengatasnamakan BRAU sebelum mendapatkan izin kerja yang sah. Dengan demikian kekisruhan ini menjadi peristiwa, yang secara signifikan berpengaruh negatif terhadap kelangsungan usaha perusahaan tercatat secara hukum. Inilah yang terus terjadi sehingga BRAU sebagai Perusahaan Tercatat tidak dapat menunjukkan indikasi pemulihan yang memadai. Dengan demikian maka dapat dikatakan bahwa BRAU telah mengalami kondisi, atau peristiwa yang secara signifikan berpengaruh negatif terhadap kelangsungan usaha Perusahaan Tercatat baik secara finansial maupun secara hukum, dan Perusahaan Tercatat tidak dapat menunjukkan indikasi pemulihan yang memadai.

2. Saham perusahaan tercatat yang akibat suspensi di pasar regular dan tunai, hanya diperdagangkan di pasar negosiasi sekurang-kurangnya selama 24 (dua puluh empat) bulan terakhir.

Selain mengalami kondisi, atau peristiwa yang secara signifikan berpengaruh negatif terhadap kelangsungan usaha Perusahaan Tercatat, penghentian sementara perdagangan saham atau suspensi merupakan salah satu faktor penyebab terjadinya delisting. Dalam hal ini terkait dengan kondisi perseroan sebelum dilakukannya penghapusan pencatatan saham

${ }^{27}$ Indonesia, Undang-Undang Tentang Pasar Modal, Pasal 86 ayat 1. 
oleh bursa (forced delisting) pada tanggal 16 November 2017, BRAU telah mengalami tiga kali suspensi yaitu terjadi pada tanggal 4 Mei 2015, 30 Oktober 2015, dan 21 Desember 2015.

Suspensi pertama, BEI melakukan suspensi atas saham BRAU karena ketidakjelasan pelaksanaan Rapat Umum Pemegang Saham Luar Biasa (RUPSLB) yang dilaksanakan 30 April 2015. Suspensi kedua, BEI melakukan suspensi atas saham BRAU karena BRAU tidak menyampaikan laporan keuangan pada Semester I-2015. Kemudian, yang terakhir, BEI memutuskan untuk memperpanjang penghentian sementara saham BRAU.

Selain Peraturan Bursa Efek Indonesia, berikut peraturan-peraturan yang juga berkaitan dengan pelanggaran yang dilakukan oleh BRAU:

a. Undang-Undang Nomor 8 Tahun 1995 tentang Pasar Modal

Selain prinsip keterbukaan melalui prospektus, Undang-Undang Pasar Modal (UUPM) juga mewajibkan emiten untuk memenuhi prinsip keterbukaan melalui pelaporan. ${ }^{28}$ UUPM mewajibkan emiten untuk menyampaikan laporan keuangan berkala dan laporan yang memuat informasi atau fakta material yang dapat mempengaruhi harga efek kepada Badan Pengawas Pasar Modal dan Lembaga Keuangan (Bapepam-LK) dan laporan itu akan diumumkan kepada masyarakat. ${ }^{29}$

b. Peraturan Otoritas Jasa Keuangan Nomor 31/POJK.04/2015 tentang Keterbukaan Atas Informasi atau Fakta Material oleh Emiten atau Perusahaan Publik

Peraturan Otoritas Jasa Keuangan ini mengatur mengenai kewajiban penyampaian keterbukaan Informasi atau Fakta Material serta jenis-jenis informasi apa saja yang wajib disampaikan oleh Emiten atau Perusahaan Publik sehingga terdapat pedoman bagi Emiten atau Perusahaan Publik atas Informasi atau Fakta Material yang harus dilaporkan kepada Otoritas Jasa Keuangan dan diumumkan kepada publik. Dengan ditetapkannya Peraturan Otoritas Jasa Keuangan ini, diharapkan kepentingan investor dapat semakin terlindungi dan kualitas keterbukaan Informasi atau Fakta Material dapat terus ditingkatkan. ${ }^{30}$

c. Keputusan Direksi PT Bursa Efek Jakarta Nomor: Kep-306/BEJ/07-2004 tentang Peraturan Nomor I-E tentang Kewajiban Penyampaian Informasi Dalam rangka meningkatkan pelindungan terhadap pemodal melalui ketentuan yang dapat meningkatkan kualitas keterbukaan informasi

\footnotetext{
${ }^{28}$ Indonesia, Undang-Undang tentang Pasar Modal, Pasal 86 angka 1 huruf a dan b.

${ }^{29}$ Ketentuan dan tata cara penyampaian pelaporan diatur lebih lanjut oleh peraturan Bapepam Nomor X.K.1 lampiran Keputusan Ketua Bapepam No. Kep.86/PM/1996 tentang Keterbukaan Informasi yang Harus Segera Diumumkan Kepada Publik dan Peraturan Bapepam Nomor X.K.2 lampiran Keputusan Ketua Bapepam No. Kep.80/PM/1996 tentang Kewajiban Penyampaian Laporan Keuangan Berkala.

${ }^{30}$ Penjelasan atas Peraturan Otoritas Jasa Keuangan Nomor 31/POJK.04/2015 tentang Keterbukaan Atas Informasi atau Fakta Material oleh Emiten atau Perusahaan Publik
} 
Perusahaan Tercatat dipandang perlu menetapkan suatu ketentuan mengenai kewajiban penyampaian laporan dan keterbukaan informasi Perusahaan Tercatat, dalam suatu Keputusan Direksi, maka untuk menyederhanakan dan memudahkan pelaku pasar memahami dan melaksanakan ketentuan pencatatan saham, maka perlu dilakukan perbaikan sistematika penyusunan dan pengelompokan ketentuan peraturan pencatatan Efek dari beberapa peraturan dan surat edaran ke dalam satu peraturan. ${ }^{31}$

\section{Perlindungan Hukum Yang Dapat Diberikan Kepada Pemegang Saham BRAU Pasca Penghapusan Pencatatan Saham Oleh Bursa (Forced Delisting)}

Kepentingan pemegang saham minoritas dalam suatu perusahaan, seringkali diabaikan atau bahkan dirugikan. Hal ini disebabkan adanya persepsi kuat, bahwa yang paling berjasa memperbesar kas perusahaan adalah pemegang saham mayoritas. Penguasaan persentase volume saham atau pemasukan modal kepada perusahaan, mendukung bukti yang kuat terhadap persepsi ini. Persepsi tersebut diperkuat lagi dengan dianutnya prinsip one share one vote dalam hukum Perseroan Terbatas sehingga dalam setiap RUPS, pemegang saham minoritas tidak akan mungkin pernah memenangkan keputusan yang diambil dalam voting. Banyak fakta membuktikan, bahwa dalam perusahaan komposisi Direksi atau komisaris senantiasa dikuasai atau dikendalikan oleh pemegang saham mayoritas. Dalam keadaan demikian pemegang saham minoritas berhak mengajukan gugatan derivative kepada Komisaris dan Direksi. Gugatan derivative yang diatur dalam Pasal 61 Undang Undang Nomor 40 Tahun 2017 bertujuan untuk melindungi hakhak dan kepentingan pemegang saham minoritas terhadap kesewenang-wenangan pemegang saham mayoritas. ${ }^{32}$ Bahkan, dalam hal-hal tertentu, pemegang saham minoritas dapat bertindak mewakili perusahaan untuk menggugat Direksi yang karena kesalahannya telah bertindak merugikan perusahaan. Selain itu, masih ada sejumlah hak-hak lain yang dapat dipergunakan oleh pemegang saham minoritas untuk melindungi dan memperjuangkan hak-hak dan kepentingannya, agar tidak dirugikan kepentingannya dalam perusahaan.

Salah satu pilar untuk melindungi pihak pemegang saham minoritas dalam suatu Perseroan Terbatas dengan menghadirkan pihak pengadilan untuk

\footnotetext{
31 Pertimbangan Keputusan Direksi PT. Bursa Efek Jakarta Nomor : Kep-306/BEJ/07-2004 Tentang Peraturan Nomor I-E Tentang Kewajiban Penyampaian Informasi

${ }^{32}$ Pasal 61 UU 40/2017

(1) Setiap pemegang saham berhak mengajukan gugatan terhadap Perseroan ke pengadilan negeri apabila dirugikan karena tindakan Perseroan yang dianggap tidak adil dan tanpa alasan wajar sebagai akibat keputusan RUPS, Direksi, dan/atau Dewan Komisaris.

(2) Gugatan sebagaimana dimaksud pada ayat (1) diajukan ke pengadilan negeri yang daerah hukumnya meliputi tempat kedudukan Perseroan.

Penjelasan Pasal 61

Gugatan yang diajukan pada dasarnya memuat permohonan agar Perseroan menghentikan tindakan yang merugikan tersebut dan mengambil langkah tertentu baik untuk mengatasi akibat yang sudah timbul maupun untuk mencegah tindakan serupa di kemudian hari.
} 
melakukan intervensi ke dalam Perseroan tersebut. Ikut campurnya pengadilan tersebut antara lain lewat gugatan derivatif dari pemegang saham yang dirugikan, tak terkecuali gugatan pemegang saham minoritas yang merasa dirugikan. Gugatan Derivatif (Derivative Action) adalah gugatan yang berdasarkan atas hak utama (primary right) dari Perseroan, tetapi dilaksanakan oleh pemegang saham atas nama Perseroan, gugatan mana dilakukan karena adanya suatu kegagalan dalam Perseroan atau dengan perkataan lain, derivative action merupakan suatu gugatan yang dilakukan oleh para pemegang saham untuk dan atas nama Perseroan. ${ }^{33}$

Gugatan derivatif adalah gugatan perdata yang ajukan oleh 1 (satu) atau lebih pemegang saham yang bertindak untuk dan atas nama Perseroan. Dengan demikian, bukan untuk kepentingan pribadi pemegang saham melainkan untuk kepentingan stakeholder secara keseluruhan. Gugatan tersebut diajukan terhadap pihak-pihak, antara lain Direksi karena telah melakukan tindakan yang merugikan Perseroan. Sekalipun demikian untuk kepentingan prosedural, dimungkinkan pihak Perseroan menjadi pihak tergugat.

Dikatakan "derivatif" (turunan) karena gugatan tersebut diajukan oleh pemegang saham untuk dan atas nama Perseroan, gugatan mana sebenarnya berasal (diturunkan) dari (derived) gugatan yang seharusnya dilakukan oleh Perseroan. Adapun yang menjadi unsur yuridis yang utama dari suatu gugatan derivatif adalah sebagai berikut: ${ }^{34}$

a. Adanya gugatan;

b. Gugatan tersebut diajukan ke pengadilan;

c. Gugatan tersebut diajukan oleh pemegang saham dari Perseroan;

d. Pemegang saham mengajukan gugatan untuk dan atas nama Perseroan;

e. Pihak yang digugat adalah Direksi maupun Komisaris dari Perseroan tersebut;

f. Sebabnya diajukan gugatan tersebut karena adanya suatu kegagalan dalam Perseroan atau kejadian yang merugikan Perseroan yang bersangkutan; dan

g. Segala hasil dari gugatan tersebut menjadi milik Perseroan, sungguh pun yang mengajukan gugatan adalah pemegang saham, sebab gugatan diajukan untuk dan atas nama Perseroan.

Terhadap gugatan derivatif, ada beberapa batasan. Batasan tersebut antara lain dimaksudkan agar terdapat keadilan bagi keseluruhan stakeholder Perseroan, bukan hanya keadilan terhadap pihak pemegang saham. UUPT membatasi gugatan derivatif (derivative action) hanya memberikan kemungkinan diajukannya gugatan tersebut kepada Direksi dan Komisaris. Sebab, yang mengajukan gugatan derivatif adalah pihak pemegang saham, dan gugatan tersebut diajukan untuk kepentingan Perseroan dalam hal adanya pelanggaran amanah atau kepercayaan (fiduciary duty)

${ }^{33}$ Munir Fuady, Perlindungan Pemegang Saham Minoritas, Bandung: CV. Utomo, 2005, hlm. 75.

${ }^{34}$ Ibid., hlm. 255. 
Dialogia luridica: Jurnal Hukum Bisnis dan Investasi

Volume 10 Nomor 2, April 2019

yang dilakukan oleh Direksi. Ketika mengajukan gugatan derivative setidaknya ada 3 (tiga) kepentingan yang perlu diperhatikan, yaitu:

a. Kepentingan Perseroan;

b. Kepentingan pemegang saham Perseroan, khususnya pemegang saham minoritas;

c. Kepentingan pihak ketiga yang melakukan hubungan hukum dengan Perseroan, khususnya kepentingan dari pihak kreditor Perseroan.

Dan ketika BRAU di dalam perusahaannya mengalami permasalahan direksi, dapat mengajukan gugatan derivatif untuk dan atas nama perseroan.

\section{KESIMPULAN}

Kesimpulan dari pembahasan di atas adalah:

Penyebab forced delisting yang dilakukan oleh Bursa Efek Indonesia yaitu karena BRAU tidak memenuhi kewajiban sebagai Perusahaan Tercatat dengan tidak memberikan laporan keuangan dan mengalami gagal membayar hutang-hutangya. Hal ini telah sesuai dengan Kep-308/BEJ/07-2004 Tentang Peraturan Nomor I-I Tentang Penghapusan Pencatatan (Delisting) Dan Pencatatan Kembali (Relisting) Saham Di Bursa, Pasal III.3, Undang-Undang Nomor 8 Tahun 1995 tentang Pasar Modal pada Pasal 86 tentang Keterbukaan Informasi dan Peraturan Otoritas Jasa Keuangan Nomor 31/POJK.04/2015 tentang Keterbukaan Atas Informasi atau Fakta Material oleh Emiten atau Perusahaan Publik.

Perlindungan hukum yang dapat dilakukan oleh pemegang saham apabila perusahaan mengalami forced delisting adalah melakukan gugatan derivatif sebagaimana diatur dalam Undang Undang Nomor 40 Tahun 2007 tentang Perseroan Terbatas.

\section{DAFTAR PUSTAKA}

\section{Buku}

Balfas, Hamud M, Hukum Pasar Modal Indonesia, Jakarta: Tatanusa, 2006.

Basir, Saleh dan Hendy M. Fakhrudin, Aksi Korporasi, Jakarta: Salemba Empat, 2005.

E. A. Koetin, Analisis Pasar Modal, Jakarta: Pustaka Sinar Harapan, 2002.

Fuady, Munir, Perlindungan Pemegang Saham Minoritas, Bandung: Utomo, 2005.

Mamudji, Sri, Metode Penelitian dan Penulisan Hukum, Jakarta: Badan Penerbit Fakultas Hukum Universitas Indonesia, 2005.

Nasarudin, M. Irsan, Et. al., Aspek Hukum Pasar Modal Indonesia, Jakarta: Prenada Media Group, 2007.

Soekanto, Soerjono \& Sri Mamudji, Penelitian Hukum Normatif (Suatu Tinjauan Singkat), Jakarta: Rajawali Pers, 2001.

Soemitro, Ronny Hanitijo, Metodologi Penelitian Hukum, Jakarta: Ghalia Indonesia, 1982. 
Dialogia luridica: Jurnal Hukum Bisnis dan Investasi

Volume 10 Nomor 2, April 2019

Sunariyah, Pengantar Pengetahuan Pasar Modal, Yogyakarta: UPP STIM YKPN, 2011.

\section{Karya Ilmiah}

Widiasmoko, Haykel, “Analisa Delisting: Penerapan Delisting di PT. Bursa Efek Jakarta dan Akibat Hukum Suatu Perseroan yang Terkena Sanksi Delisting”, Skripsi Universitas Indonesia, 1999.

\section{Jurnal}

Martinez Isabelle, "Reasons for Delisting and Consequences: A Literature Review and Research Agenda", Journal of Economic Surveys, Volume 31 Issue 3, 2016.

\section{Internets}

Angga Aliya, "Berau Coal Tak Mampu Bayar Utang Rp 5,8 Triliun", Detik Finance, diakses dari https://finance.detik.com/bursavalas/2965830/berau-coal-tak-mampu-bayar-utang-rp-58-triliun, diakses pada tanggal 17 November 2018 pukul 17.11 WIB

Danang Sugianto, "Saham Berau Dulu Primadona, Sekarang 'Ditendang' dari Bursa", Detik Finance, diakses dari https://finance.detik.com/bursavalas/3695726/saham-berau-dulu-primadona-sekarang-ditendang-daribursa, diakses pada tanggal 16 November 2018 pukul 16.07 WIB

Lukas Hendra TM, "Berau Coal Energy (BRAU) Resmi Jadi Perusahaan Tertutup", Bisnis.com, diakses dari http://market.bisnis.com/read/20171115/192/709416/berau-coal-energybrau-resmi-jadi-perusahaan-tertutup, diakses pada tanggal 17 November 2018 pukul 16.11 WIB

Rheza Andhika Pamungkas, "Listing Perdana, Saham Berau Langsung Melesat", Okezone Finance, diakses dari https://economy.okezone.com/read/2010/08/19/278/364378/listingperdana-saham-berau-langsung-melesat, diakses pada tanggal 16 November 2018 pukul 16.11 WIB

\section{Peraturan Perundang-undangan}

Indonesia, Undang-Undang Nomor 8 Tahun 1995 Tentang Pasar Modal, Lembaran Negara (LN) Tahun 1995 Nomor 64, dan Tambahan Lembaran Negara (TLN) Nomor 3608.

Keputusan Direksi PT. Bursa Efek Jakarta Nomor: Kep-306/BEJ/07-2004 Tentang

Peraturan Nomor I-E Tentang Kewajiban Penyampaian Informasi

Keputusan Ketua Bapepam No. Kep.80/PM/1996 tentang Kewajiban Penyampaian Laporan Keuangan Berkala. 
Dialogia luridica: Jurnal Hukum Bisnis dan Investasi

Volume 10 Nomor 2, April 2019

Keputusan Ketua Bapepam No. Kep.86/PM/1996 tentang Keterbukaan Informasi yang Harus Segera Diumumkan Kepada Publik

Peraturan No. I-I Tentang Penghapusan Pencatatan (delisting) dan Pencatatan Kembali (relisting) saham di bursa Keputusan Direksi PT. Bursa Efek Jakarta No. Kep-308/BEJ/07-2004.

Peraturan Otoritas Jasa Keuangan Nomor 31/POJK.04/2015 tentang Keterbukaan Atas Informasi atau Fakta Material oleh Emiten atau Perusahaan Publik

Peraturan Pencatatan Efek No. I-A Tentang Pencatatan Saham dan Efek Bersifat Ekuitas Selain Saham yang Diterbitkan oleh Perusahaan Tercatat, Keputusan Direksi PT. Bursa Efek Jakarta No. Kep-305/BEJ/07-2004. 